Turkish Online Journal of Qualitative Inquiry (TOJQI)

Volume 10, Issue 4, October 2019: 462-489

DOI: $10.17569 /$ tojqi.615378

Research Article

\title{
STEM Education for Disadvantaged Students: Teacher and Student Experiences ${ }^{1}$
}

\author{
Esra Bozkurt Altan ${ }^{2}$, Esra Köroğlu ${ }^{3}$
}

\begin{abstract}
STEM education is based on interrelated and holistic teaching of the disciplines of science, technology, engineering and mathematics. It is important to ensure that STEM education does not address a certain category of society only but that it is also applied to disadvantaged segments of society. The aim of the present study is to identify the opinions of socioeconomically disadvantaged students and their teachers about STEM education experience. The study was planned according to the case study model. The participants of the research consisted of a teacher and 34 Grade- 8 students studying in a regional boarding school (RBS) in a northern province of Turkey. In the study, a unit (Living Beings and Life) within the scope of 8th grade science course was planned in accordance with STEM education. The data of the study were collected through student diaries and the field notes taken by the teacher. The data obtained from student diaries were subjected to content analysis, and the field notes were analysed with descriptive analysis. It was determined that the RBS students evaluated STEM-focused activities and the related applications in terms of their contributions to their learning process, 21st-century skills, their perceptions about STEM disciplines and the development of their career awareness on STEM fields. The results obtained from the teachers' field notes showed that the students' participation and group work skills increased, that the students had fun and became motivated in the course, and that they experienced an improvement in their skills of associating what they learned with their daily life, solving problems and designing and in their engineering awareness.
\end{abstract}

Keywords: Disadvantaged students, regional boarding secondary school students, social justice, STEM

\footnotetext{
${ }^{1}$ This research was prepared by organizing a part of the master thesis of the second author under the supervision of the first author.

${ }^{2}$ Dr. Lecturer, Corresponding Author, Sinop University, College of Education, Science and Mathematics

Education Department, esrabozkurt@ sinop.edu.tr, https://orcid.org/0000-0002-5592-1726

${ }^{3}$ Science Teacher, Ministry of Education, https://orcid.org/0000-0001-9270-0992
} 


\title{
Dezavantajlı Öğrenciler için STEM Eğitimi: Öğretmen ve Öğrenci Deneyimleri
}

\author{
$\ddot{\mathbf{O z}}$
}

STEM Eğitimi, fen, teknoloji, mühendislik ve matematik disiplinlerinin birbiri ile ilişkili ve bütüncül öğretimini esas almaktadır. STEM eğitiminin toplumun yalnızca belirli bir kesimine hitap etmesinden kaçınılması ve toplumun dezavantajlı kesimlerine de uygulanması önem arz etmektedir. Araştırmanın amacı sosyo-ekonomik olarak dezavantajlı öğrencilerin ve öğretmenlerinin STEM eğitimi deneyimine yönelik görüşlerini ortaya koymaktır. Araştırma durum çalışması modelinde planlanmıştır. Araştırmanın çalışma grubunu Türkiye'nin kuzeyinde bir ilde yatılı bölge okulunda öğrenim görmekte olan 34 sekizinci sınıf öğrencisi ve bir fen bilimleri öğretmeni oluşturmuştur. Araştırmada 8. sınıfı fen bilimleri dersi kapsamında bir ünite (Canlılar ve Hayat) STEM eğitimine uygun olarak planlanmıştır. Araştırmanın verileri öğrencilerin günlükleri ve uygulayıcı tarafından tutulan alan notları ile toplanmıştır. Öğrencilerin günlüklerinden elde edilen verilerin analizi içerik analizi ile, alan notları ise betimsel analiz ile çözümlenmiştir. Yatılı bölge okulu öğrencileri STEM odaklı etkinlikler ile yürütülen uygulamaları; öğrenme sürecine, 21. Yüzyıl becerilerine, STEM disiplinlerine yönelik algılarına ve STEM alanlarında kariyer farkındalığına olumlu etkisi olduğu şeklinde değerlendirmiş̧lerdir. Uygulayıcı ise, uygulamaların öğrencilerin derse katılımını ve grup çalışması becerisinin arttığını, öğrencilerin derste eğlendiklerini ve motive olduklarını, günlük yaşam ile öğrendiklerini ilişkilendirme, problem çözme ve tasarım becerilerinin gelişimini sağladığı ve mühendisliğe yönelik farkındalıklarının gelişim gösterdiği şeklinde değerlendirmiştir.

Anahtar Sözcükler: Dezavantajlı öğrenciler, yatılı bölge ortaokulu öğrencileri, sosyal adalet, STEM. 


\section{Introduction}

The abbreviation STEM (Science, Technology, Engineering, Mathematics) represents one of the educational approaches that propose the integration of disciplines which have become very popular in the international literature. This educational approach is based on the interrelated and holistic teaching of the disciplines of science, technology, engineering and mathematics. The main point of this approach is to ensure that individuals are faced with problems which are compatible with the real lives and contexts of individuals, which require them to employ their knowledge and skills about the disciplines of science, technology, engineering and mathematics and which have multiple solutions, and that they produce solutions for these problems (Sanders, 2009; Shaughnessy, 2013; Smith \& Karr-Kidwell, 2000). The process of finding solutions to real life problems ensures to improve individuals' 21 st-century skills such as entrepreneurship, innovation, creative thinking, decision making and problem solving in addition to their knowledge and skills related to STEM disciplines (Ellis \& Fouts, 2001; Rogers \& Portsmore, 2004; Schnittka \& Bell, 2011; Smith \& Karr-Kidwell, 2000) and to raise their interest in and career awareness about STEM fields (Dubetz \& Wilson, 2013; Gülhan \& Şahin, 2016). The influence of the developments in the fields of science, technology, engineering and mathematics on the economic development of countries in the present century makes it important for individuals to increase their interest and career awareness (National Academy of Engineering [NAE] \& National Research Council [NRC], 2009; NRC, 2012). However, the multidisciplinary nature of real-life problems and also factors like the contribution of this approach to the skills individuals should have in the 21 st-century can be considered as important reasons for which this approach has become popular.

There are many studies on how STEM education, which is related to this highly popular approach, will be carried out in education systems with disciplinary education programs, how to improve teachers' qualifications, how STEM education will be applied with various methods, and its impact on students (Doppelt, Mehalik, Schunn, Silk \& Krysinski, 2008; Ellefson, Brinker, Vernacchio \& Schunn, 2008; Wendell, 2008). Despite the existence of numerous studies in literature, attention is drawn to the fact that applications which are not compatible with the purposes of STEM education can be encountered in Turkey (Çepni, 2017; Karahan, 2015; Sar1, 2018). Examples include workshops like coding, robotics and object designing with 
3D printers, which involve following certain process steps that do not allow students to employ processes like computational thinking and problem solving. This situation may lead to the perception that STEM education addresses the middle/upper segment of society in socioeconomic terms. Of course, robotic applications and coding works can be part of STEMfocused learning environments in which the learning process is planned properly. This is because applications such as coding that contribute to computational thinking skills are very important for preparing individuals beyond the century we live in (Çorlu, 2017). However, they need to be planned as part of learning processes that are in line with the requirements of STEM education. On the other hand, the understanding that makes robotic applications inevitable can lead to the perception that STEM education addresses only the upper segments of society (Karahan, 2015). As a matter of fact, the applicability of STEM education to socioeconomically disadvantaged groups is among the issues mentioned in the literature.

\section{Socio-Economically Disadvantaged Groups, Social Justice and STEM Education}

It is seen that studies in international literature have been recently emphasising the necessity of applying STEM education also to the disadvantaged segments of society instead of addressing only a specific segment. These studies are observed to deal with STEM education for disadvantaged groups (Lowrie, Downes \& Leonard, 2018) or STEM education and social justice (Sondel, Koch, Carrier \& Walkowiak, 2017).

Social justice is defined by the Turkish Language Institution (2018) as "The equilibrium provided in the social sphere by taking the measures of life standard, income level etc. in different parts of society into consideration within the framework of equality of opportunity". It is addressed in education in terms of dimensions like distribution (Gale, 2000; Gewirtz, 2006; Sturman, 1997), recognition (Gale, 2000; Gewirtz, 2006; Sturman, 1997) and participation (democracy) (Enslin, 2006). Distribution refers to the distribution of opportunities proportionately for everyone, and recognition refers to an education which includes all the groups that can be considered disadvantaged in terms of factors like race, socio-economic status and gender and which also ensures that they recognise the social structure that they live in. Participation means the configuration of education so as to help individuals to develop themselves and participate in social life. Since social justice in education promotes social rights and provides an opportunity for good education for all segments of society, this will strengthen 
the political and financial situation and instil a hope of renewal in society (Alsubry \& Shaw, 2005).

Some of the studies addressing STEM education from the framework of socio-economically disadvantaged groups and social justice are as follows: According to Scott (2017), although budget planning and economic infrastructure can prevent STEM education from reaching all segments of society, this should be overcome, and effectively educating the teachers of the future in universities is an important way to ensure social justice in STEM education. Wong, Dillon, and King (2017) reviewed government-issued reports on the objectives, management and financial resources of STEM education in the UK, and interviewed relevant people such as science, mathematics, engineering educators on the advantages and possible disadvantages of STEM education. The point to which the researchers drew attention the most at the end of this comprehensive study is that the structuring of the disciplinary courses of science and mathematics in order to improve STEM literacy is not compatible with industrial and political demands. In the study, the industrial need for individuals who have high literacy in STEM fields and who can specialise in these fields was evaluated together with the cost obligation that is entailed by an application of STEM education at all levels. In this situation, the applicability of STEM education for students in science and mathematics only after 16 years of age was considered as a suitable solution. Pointing out that this situation prevents the application of STEM education in a way that provides social justice, the researchers emphasise the necessity of carrying out more studies on how to implement STEM education so as to provide social justice. Parker, Pillai, and Roschelle (2016) organised a forum on "Next Generation STEM Learning for All" supported by the American National Science Foundation (NSF) and attended by STEM-related scientists, schools, politicians and the public in 2015. The researchers stated in the report they prepared after the forum that during all sessions the participants considered STEM education as a social justice issue. It is emphasised in the report, among others, that providing opportunities for creating STEM learning environments for generally underrepresented students in STEM fields (such as female students, disabled people, socioeconomically disadvantaged groups, etc.) will contribute to social justice.

STEM education and social justice were also covered by the special issue of a magazine (Catalyst) in 2017 (Scott, 2017). Among the authors whose studies were published in that issue, Madden, Wong, Vera Cruz, Olle, and Barnett (2017) present a framework for applying STEM 
education with a focus on social justice as an out-of-school program. The researchers point out that they are not sure how coding and robotics can provide social justice and they draw attention to the importance of their research on how to implement STEM education within the framework of social justice. In their study on the inadequacy of African Americans in STEM (Science, Technology, Engineering and Mathematics) fields, Bannister, Davis, Mutegi, Thompson, and Lewis (2017) emphasise regarding this failure in STEM fields that it is not sufficient to focus on the relationships among factors such as culture, race, power, class, learning preferences, cultural styles and language. In consideration of the necessity for STEM teacher educators and teachers to focus on the social situation of African-Americans when structuring pedagogy and other important factors like education content, the researchers provided a framework on how learning and teaching of mathematics can be carried out for this disadvantaged group.

When the concepts of social justice and STEM education are taken together, creation of learning environments suitable for STEM education for socio-economically disadvantaged groups and identification of student and teacher experiences in these environments are important in terms of contributing to the teachers and researchers who aim to prepare a learning environment suitable for STEM education towards disadvanteges students. In this study, a learning environment was created for regional boarding secondary school (RBS) students, one of the disadvantaged groups, and the views of practitioner teachers and students were presented. Boarding regional secondary schools were established in order to meet the educational needs of poor family children who have reached compulsory education age in settlements where the population is small and scattered (MoNE, 2003). Additionally, studies revealing that RBS students have low awareness about career options in STEM fields (Bozkurt Altan, Üçüncüoğlu \& Zileli, 2019) show that the present study will contribute to the field in this sense as well.

In the present study, a science teacher who decided to improve themselves in STEM education after receiving in-service education planned a course unit in accordance with STEM education. It is believed within the context of this study that presenting the opinions of an experienced teacher who plans and implements activities for disadvantaged students will also contribute to the field in terms of the applicability of STEM education and the importance of teacher education. As a matter of fact, the desire of carrying out STEM education for everyone renders the education of teachers important. Various researchers also reveal the need for teachers and teacher candidates to carry out STEM education (Bozkurt Altan \& Ercan, 2016; Hacioğlu, 
Yamak \& Kavak, 2016, 2017; Han, Yalvaç, Capraro \& Capraro, 2015; Üçüncüoğlu, 2018; Wang, Moore, Roehrig \& Park, 2011). In their studies, Bozkurt Altan, and Ercan (2016), Çınar, Pırasa, and Paliç Sadoğlu (2016), Hacıoğlu et al. (2016, 2017) and Üçüncüoğlu (2018) reported that as the education and experience of teachers and teacher candidates about STEM education increase, their interest and abilities in this subject will also increase. Kınık Topalsan (2018) argued that STEM-educated class teacher candidates perform poorly in creating appropriate problems when developing teaching activities based on engineering design. Peterman, Daugherty, Custer, and Ross (2017) point out that although teachers receive education about STEM education, they do not have sufficient pedagogical knowledge about it. In this context, the tendency of teachers to develop themselves in the end of the education they receive may support the dissemination of STEM education and its applicability for disadvantaged groups. Teacher education will undoubtedly be important for teachers to prepare appropriate problem cases and to plan activities suitable for STEM education in their classrooms with simple materials.

The aim of the study is to identify the opinions of the regional boarding school (RBS) students and the practitioner teacher about STEM education experience.

\section{Methodology}

In this study, all stages such as determination of the study group, data collection process and data analysis were planned based on qualitative research methodology.

\section{Study model}

This study was planned as a holistic multiple case study, which is one of the qualitative research methods. There are multiple case in the holistic multiple case study desing, each case is evaluated and compared in its entirety (Yin, 2009). Within the scope of the study, the 8th grade "Living Beings and Life" unit was planned within the framework of STEM-focused activities. The aim was to identify the experiences and opinions of the practitioner teacher and the students. The multiple case examined in the study is the views of the RBS students and the practitioner teacher about STEM-focused activities. The results of the experiences of the 
students and teachers were discussed together and it was aimed to reveal the experiences for the implementation of STEM-focused activities for disadvantaged students.

\section{Participants}

The study group of the research consisted of a science teacher and 34 Grade- 8 students (18 female, 16 male) studying in a regional boarding school (RBS) in a Black Sea province of Turkey. The study group was determined by convenience sampling as one of the purposive sampling methods. The reason for selecting these regional boarding school students as the study group is that the students attending this school represent a disadvantaged group in terms of socio-economic status. All of the students in the study group are based in low-populated villages at least $40 \mathrm{~km}$ from the school and are boarding students. The average monthly income of their families is at or below the minimum wage. In this respect, in accordance with the STEM education and social justice context of the study, the RBS students formed the study group of the research. The teacher who conducted the STEM activities is a science teacher who has 8 years of experience including 7 years in the RBS. Before this study, the science teacher participated in a 60-hour education program consisting of theoretical and practical content for the theoretical basis of STEM education, application examples, and its application in science classes. Then the science teacher began to have graduate studies and took elective courses for interdisciplinary education. It is important that the teacher has both teaching experience for the disadvantageous group and STEM education in order to show that the study is in line with the objectives.

\section{Context of Research}

Within the scope of the research, STEM-oriented activities were planned in accordance with the acquisitions of the "Living and Energy" unit, which is the 5th unit of the 8th grade of the Science Education Program (2016). Within the scope of the study, the "Living Beings and Energy" unit, which is the $5^{\text {th }}$ unit of Grade 8 , was planned in accordance with STEM education. Seven different activities were prepared accordingly. The activities developed and the teacher guide drawn up to facilitate the implementation of the activities were presented as abstract submission (Köroğlu \& Bozkurt Altan, 2017). 
The activity development process was carried out as follows: Taking the structure and scope of the gains relating to the "Living Beings and Energy" unit into consideration, how the unit could be planned in accordance with STEM education was examined and a draft was drawn up. In this context, alternative activities were designed for one or more gains. All of these activities are aimed at preparing a STEM-focused learning environment with design-based learning, problem-based learning and project-based learning (Bozkurt Altan, 2017a, b). The general framework for the preparation of the activities is as follows: The problem situation including the knowledge and skills related to at least two of the STEM disciplines should be presented, the problem should be appropriate to the context of the students, the problem should have multiple solutions.

The suitability of the prepared activities to the STEM education concept was examined by 2 science education experts and 1 science expert who have experience in the field. The suggestions made included to enrich the integration of the disciplines (to integrate another discipline into the activity), to plan classroom time, and to make it a little easier to be appropriate to the level of the students, etc. The necessary corrections were made in accordance with the suggestions received and sent back to the experts for approval. The activities were examined by 1 Turkish Language teacher for an evaluation of expression. Corrections regarding language and expression were made accordingly. Information on the activities prepared for each / several learning outcome in the unit is presented in Table 1.

Table 1

The Content of "Living Beings and Energy" Unit STEM-Focused Activity Modules and Related Learning Outcomes

\begin{tabular}{|c|c|c|}
\hline Learning Outcomes & Activity Name & Integrated STEM Disciplines \\
\hline $\begin{array}{l}\text { Students understand the producer-consumer- } \\
\text { decomposer relationship in food chain, and give } \\
\text { examples. }\end{array}$ & $\begin{array}{l}\text { Daily Life and } \\
\text { Food Chain }\end{array}$ & $\begin{array}{l}\text { Science, Mathematics } \\
\text { (Problem-based Learning) }\end{array}$ \\
\hline $\begin{array}{l}\text { Students comprehend the importance of } \\
\text { photosynthesis in food production and explain how } \\
\text { photosynthesis takes place. It is emphasised that } \\
\text { photosynthesis also occurs in artificial light. } \\
\text { They understand the importance of respiration in } \\
\text { living organisms and explain how respiration occurs. }\end{array}$ & $\begin{array}{l}\text { We Are } \\
\text { Designing a } \\
\text { Greenhouse }\end{array}$ & $\begin{array}{l}\text { Science, Mathematics, } \\
\text { Engineering } \\
\text { (Engineering design process) }\end{array}$ \\
\hline $\begin{array}{l}\text { Students explain cycles of matter by showing them on } \\
\text { a diagram. } \\
\text { They question the importance of cycles of matter for } \\
\text { life. }\end{array}$ & $\begin{array}{l}\text { Cycles of } \\
\text { Matter - } \\
\text { Environmenta } \\
\text { n Engineers at } \\
\text { Work }\end{array}$ & $\begin{array}{l}\text { Science, Technology, } \\
\text { Engineering, Mathematics } \\
\text { (Engineering design process) }\end{array}$ \\
\hline
\end{tabular}




\begin{tabular}{|c|c|c|}
\hline Learning Outcomes & Activity Name & Integrated STEM Disciplines \\
\hline $\begin{array}{l}\text { They investigate the causes of ozone depletion and its } \\
\text { possible effects on living beings, and produce and } \\
\text { present suggestions for the solution of the problem. }\end{array}$ & $\begin{array}{l}\text { The Top of the } \\
\text { Earth Was } \\
\text { Opened }\end{array}$ & $\begin{array}{l}\text { Science, Mathematics } \\
\text { (Project-based learning) }\end{array}$ \\
\hline $\begin{array}{l}\text { Students design projects for the efficient use of } \\
\text { resources. } \\
\text { Using research data, they discuss the importance of } \\
\text { separating solid wastes for recycling and its } \\
\text { contribution to the national economy, and offer } \\
\text { solutions for this issue. }\end{array}$ & $\begin{array}{l}\text { Recovery } \\
\text { Recovers the } \\
\text { Future }\end{array}$ & $\begin{array}{l}\text { Science, Technology, } \\
\text { Mathematics } \\
\text { (Engineering design process) }\end{array}$ \\
\hline $\begin{array}{l}\text { Using research data, students discuss the positive and } \\
\text { negative effects of current biotechnology applications. } \\
\text { They research and report on the development of bio- } \\
\text { technology applications from past to present. }\end{array}$ & $\begin{array}{l}\text { Genetically } \\
\text { Modified } \\
\text { Organisms } \\
\text { (GMOs) }\end{array}$ & $\begin{array}{l}\text { Science, Mathematics } \\
\text { (Problem-based learning) }\end{array}$ \\
\hline $\begin{array}{l}\text { Students research the groups of professions related to } \\
\text { bio-technological studies, and explain the activity } \\
\text { areas of these groups. }\end{array}$ & $\begin{array}{l}\text { Professions } \\
\text { Contest: The } \\
\text { Professions of } \\
\text { the Future }\end{array}$ & $\begin{array}{l}\text { Science, Technology } \\
\text { (Project-based learning) }\end{array}$ \\
\hline
\end{tabular}

Daily Life and Food Chain: In this activity, the students were presented with a newspaper report on the colour of Tuz Gölü (Salt Lake) turning red in certain periods of the year. Modelling the food web in the lake, the causes of redness and solution suggestions were discussed. Before presenting the problem case, real life problems were presented and researches were made to establish the context about food web, food chain and the producer-consumer-decomposer relationship. In one of the researches made in this context, the students were asked to take a photo of a living creature and form a food web consisting of at least 5 living creatures including the photographed one.

We Are Designing a Greenhouse: In this activity, the students were presented a problem case within the context of designing a greenhouse in accordance with real life contexts. They did group work in the activity. The design of the group which achieved the most successful solution in terms of all criteria was applied in the school yard. Mini design and research tasks were planned whereby the students would acquire the knowledge and skills they needed to acquire for this design that requires taking into account many factors such as the temperature, humidity, sunshine duration, respiration and photosynthesis in their districts.

Cycles of Matter - Environmental Engineers at Work: In this activity, a design problem was presented to the students, who were to plan a living space considering the important elements of the nitrogen, water and carbon cycle. They had to make an environmental decision to plan the living space in accordance with the criteria presented regarding all these cycles. Mini designs and researches were prepared for the students to gain knowledge and skills about the 
water, carbon and nitrogen cycle. Two-dimensional models were built out of the design solutions they developed.

The Top of the Earth Was Opened: In this activity, a fictional story about the problems that may arise as a result of thinning of the Ozone Layer was presented and discussed. Then, the students were asked to design a digital story about the reasons of ozone depletion and their solutions. Information was given about digital story design and the criteria to be considered. The students' stories were evaluated with a rubric.

Recovery Recovers the Future: In order to establish the context in this activity, data on how the separation of wastes can contribute to the national economy were distributed and inferences were made on the data. Then, waste bags containing different types of solid wastes (plastic, paper, cardboard, plastic bags, etc.) were distributed to the groups and they were asked to separate and use them to develop products that can meet a need considering the criteria such as usefulness, aesthetics, etc.

Genetically Modified Organisms (GMOs): In this activity, the students are presented a few examples of the positive and negative consequences of bio-technology applications and these positive/negative aspects are discussed. The class is then divided into 2 groups to collect data on the positive and negative aspects of biotechnology applications. A discussion is made in the next lesson. The students are then presented with a problem case in which they must decide whether or not to use biotechnology applications. The problem case is planned to allow them to make decisions by analysing numerical data and looking at the subject from various angles.

Professions Contest - The Professions of the Future: Professional groups related to biotechnological studies were discussed and each group was asked to design digital stories in order to introduce these professions by storytelling.

The activities were conducted in the school classroom, computer lab and school yard. Some lecture hours were carried out in the computer laboratory for the students to conduct research. Each group has a computer. The activities were carried out with group work. In forming groups, the principles of group formation in collaborative learning were taken into consideration. The groups that were forced in the activities joined the other groups and completed the activities by 
exchanging ideas where they were forced. While the students were working in the computer lab, they worked with group friends on a computer for 2 people. The computer laboratory is Ushaped. Some groups have completed their activities with the help of other friends and teachers in the areas where they have difficulty in doing research.

\section{Data Collection Instruments}

The data of the study were collected through the diary entries that each student wrote after carrying out STEM-focused activities and the field notes kept by the practitioner teacher. After each activity from the beginning of the implementation of STEM-focused activities, the students were asked to write a diary entry for the practice they performed on that day. No limitation was imposed regarding the diary-keeping of the students, and it was stated that they could address any factor such as the activity carried out, the teacher, individual and group performances, and their feelings and thoughts. During the process, each student prepared seven diaries. The practitioner kept the field notes on the basis of what skills the students employed in the activities and how their reactions were during the activities. The science teacher also noted the important points of the course because he was the person carrying out the process, and prepared field notes at the end of the course. The science teacher also prepared seven field notes.

\section{Data Analysis}

The data obtained from the students' diaries were subjected to content analysis, all diaries were examined separately by both researchers, and codes were formed. The two researchers came together, compared the compatibility and frequency of the codes, discussed their differences, and finalised the code scheme. Then, it was discussed in which themes the codes will be addressed and it was decided to address the evaluations of the students about the activity in the themes of contributions to the process of learning, contributions to the development of 21 stcentury skills, contributions to the development of career awareness about STEM fields, and contributions to the perception about STEM disciplines (See Appendix1 Analysis Framework of Students' Diaries). Field notes were also analyzed by content analysis. The issues stated by the teacher in the field notes were coded both by him and the other researcher. Themes were created from the obtained codes. Three of the themes were similar to those derived from the 
analysis of the student diaries mentioned above. In addition to these themes, the theme of difficulties experienced in the process has emerged. (See Appendix2 Analysis Framework of Teachers' Field Notes).

\section{Findings}

Findings relating to the evaluations of the RBS students about their STEM education experience are given in Table 2.

Table 2

Findings about the Evaluations of the RBS Students about Their STEM Education Experience

\begin{tabular}{llc}
\hline Theme & Code & Frequency \\
\hline Contributions to the Process of & Fun & 33 \\
Learning $(\mathrm{N}=100)$ & Connection to daily life & 27 \\
& Permanent learning & 20 \\
& Motivates to learn & 20 \\
Contributions to the Development & Research and inquiry & 21 \\
of 21st_Century Skills (N=76) & Group work & 21 \\
& Problem-solving skill & 20 \\
& Designing skills & 14 \\
\hline Contributions to the Perception & Science and engineering & 16 \\
about STEM Disciplines (N=75) & relationship & 16 \\
& How do engineers work? & 16 \\
& How do scientists work? & 15 \\
& Science and mathematics & 12 \\
& relationship & 17 \\
\hline Contributions to Developing STEM & Interest in engineering & 13 \\
& Interest in becoming a & \\
\hline Career Awareness (N=30 & scientist & \\
\hline
\end{tabular}

An examination of Table 2 shows that the evaluation of the RBS students about STEM-focused applications is mostly based on their contributions to the process of learning $(\mathrm{N}=100)$. It is followed by the contributions to 21 st-century skills $(\mathrm{N}=76)$, contributions to their perceptions about STEM disciplines ( $\mathrm{N}=75)$, and contributions to developing STEM career awareness $(\mathrm{N}=30)$. 
The RBS students described the contributions of STEM-focused activities to the process of learning in terms of the activities being fun $(f=33)$, their enabling to make connections to daily life ( $\mathrm{f}=27)$, their enabling to learn permanently $(\mathrm{f}=20)$ and the problems being motivating for learning $(\mathrm{f}=20)$. The statements of some of the students who expressed their opinions on this theme are as follows:

"After we did these designs, I started to have a very good time in the class and became more interested in it. Everything was always fun... ",

"It was fun for me to find a solution to a real event that can happen around us, and it attracted me to the course.",

"I enjoyed doing the designs. We worked on problems that are actually relevant to our country. That was good."

The RBS students, who evaluated STEM-focused activities as contributing to the development of 21st-century skills, stated that the activities contributed to the development of their skills of research-inquiry ( $f=21)$, group work $(f=21)$, problem-solving $(f=20)$ and designing $(f=14)$. The statements of a few students who expressed opinions on this theme are as follows:

"Recycling was actually a difficult task, but we overcame it together with our group friends. We did a great job. We were good at completing a task together.",

"I had a hard time setting criteria and constraints in the recycling problem. But now I can well distinguish criteria and constraints in a problem, and develop solutions."

In their diaries, the RBS students stated that the process contributed to improving their perceptions of STEM disciplines. The students pointed out that they were able to make inferences about the science and engineering relationship ( $f=16)$, how engineers $(f=16)$ and scientists $(\mathrm{f}=16)$ work, and the relationships between science and mathematics $(\mathrm{f}=15)$, and between engineering and mathematics $(\mathrm{f}=12)$. The views of a few of the students are as follows:

"When I worked like an engineer, I realised that engineers created new products for us by using the subjects of science. Greenhouse construction is an example. Photosynthesis is a science subject. Taking this into consideration, it is engineering to design a greenhouse according to the criteria at hand. 
"For example, we learn the importance of separating solid wastes and how to separate them for recycling. Engineers build recycling facilities using this information."

"An engineer can transform the facts determined by scientists into a product. The buoyancy of water is related to science. Engineers use this knowledge to design ships."

The contribution to developing STEM career awareness was another theme that the RBS students drew attention to in their evaluations about STEM-focused applications. At the end of the activities, the students mentioned their interest in engineering $(\mathrm{f}=17)$ and being a scientist $(\mathrm{f}=13)$. Here are a few student statements:

"This activity made me realise some problems and thus I both learned the problem and also how to solve it. For example, as I approach the problem about food chain, now I can better understand what this problem is and think better for a solution; perhaps one day I will be interested in science as well."

"I realised that I also like designing something."

In the field notes, it was determined that the observations of the teacher in the process were collected on the themes of contribution to learning process, development of 21 st century skills, STEM career awareness, and the difficulties experienced in the process.

In the field notes, the contributions to the learning process are discussed within the framework codes of funning, connection to daily life, motivates to learning. The most frequently mentioned issue in the field notes was that those students who did not participate in the previous courses showed a noticeable participation in all courses in which STEM activities were applied. The activities have led to an increase in class participation. This situation is considered as code of motivates to learning. The science teacher stated this in a few notes as follows:

"The students named Student1 and Student2 had little interest in the course. They started participating in the course in these activities and Student2, who had learning difficulties, raised his hand many times to speak.",

"Student3 was a very quiet student, he didn't like to participate in the course, but when we were discussing a problem case about food chain, he raised his finger to give an answer and made a good comment. His behaviour surprised even his friends.", 
"I was astonished to see Student4, a special education student, discussing with her friend about what happens when each of the living beings is removed from a food web. In the same way, Student 5 didn't used to participate in the course very much, but when I visited the groups, I saw that he was interested in it, too."

In the field notes, the teacher frequently stated that the students enjoyed all STEM activities in the theme of contributions to the learning process and that they had great fun. This situation has been evaluated in the code of fun process within the scope of the theme of contributions to the learning process. The science teacher stated this in a few notes as follows:

"They asked for permission from a family in the village for entering their stables and coops and taking photos of cows, sheep and chickens. When they finally returned, they said they enjoyed it very much."

"The most entertaining part was the one about 'let's rescue the Tuz Gölü (salt lake) from the redness".

"The students enjoyed it very much. In fact, at the end of class, they said to each other how beautiful it was. They didn't even go out during the break time."

It has been found that the teacher reflects his observations about the students' connection with daily life in the theme of contributions to the learning process. It was observed that the fact that the students were faced with problems from daily life improved their ability to associate what they learned with their daily life. Greenhouse design, for example, not only motivated them in the learning process since it is a context from their daily lives, but also led them to share their knowledge with their families. The statements recorded in the field notes are:

"Since some of the students had already seen greenhouses in their villages, they directly began design drawing. This subject caught their attention much because it was a subject that was around them; all of them were familiar with agriculture. They enthusiastically said that they would convey the information they learned to their families."

The teacher notes in his field notes reflect his observations on the development of group work, problem solving and design skills in the theme of the development of 21 st century skills. One of the facts frequently mentioned skills in the field notes is that group work developed in these activities although the students had not wanted to do group work, or they had had disagreements in previous activities. It is believed that this was because they realised that there was a need to do group work in the activities. This is stated in the field notes as follows: 
"I had organized mixed groups including boys and girls. Not getting along well in group works, they objected to this as well. I said to them that the activities could only be done with group work. After the first activity, they were very friendly with each other and could listen to each other."

"Some students said that the best solution was theirs. But they were surprised when they saw that some of the other students in the group had very good ideas, and thus they began to care about the ideas of their friends in the group."

One of the skills that the teacher indicated in the theme of the development of 21st century skills was design skills improved during the process. It was noted that, after the first activity, they did not experience any problems about determining criteria and constraints, and that they showed improvement in issues such as finding solutions and choosing the best according to criteria and constraints.

"In the recycling activity, they operated the design process so well that I observed that they discussed each solution feverishly in accordance with the criteria and constraints."

One of the skills that the teacher indicated in the theme of the development of 21 st century skills was the problem solving skills. One of the important observations was that students were now able to understand problems better and carry out problem-solving processes faster. The practitioner expresses this situation in the field notes as follows:

"Today in our third activity, unlike the previous ones, they can immediately understand the problem case and make inferences about what are wanted. In fact, I've seen that the groups can quickly suggest many solutions."

It was determined that the teacher's field notes reflect his observations on the development of interest in engineering in the theme of STEM career awareness. It was stated in the field notes that the students can develop awareness about the profession of engineering as implied by the fact that they did not fail to ask during design and technology activities which fields of engineering were concerned with those activities.

"After the greenhouse activity, they asked me whether environmental engineers or agricultural engineers did this job, and I discussed it with them."

"In the recycling activity, they asked which engineers were involved in the building of separation mechanisms." 
In the field notes, it was found that the teacher made observations within the scope of the difficulties experienced in the process within the scope of the mathematical skills of students and the negative impact of academic achievement.

It is indicated that the activities in which mathematics integration was carried out such as table interpretation, graphic examination, model building, and proportional reasoning were the parts in which the students had the hardest time. It is even noted that there were some students who said they were bored when they faced that subject.

"In our activity, they had trouble when mathematics was concerned. Some students had difficulty in that part, and two groups were united to try to solve it."

"What they had to do about mathematics was table interpretation but I think they have prejudices because they said they had difficulty with it."

An important point in the field notes was that a few students with high academic achievement did not want to participate in the first activities. It was found that they initially wanted to solve tests but subsequently began to enjoy the activities in the process. An exemplary statement in the field notes is as follows:

"I couldn't fully understand why some very good students in the class remained passive in the first activity. The activities were different from what they had been used to so far; they seem to be afraid of not being successful."

The matters pointed out in the field notes included the fact that the students' course participation and their skill of group work improved, that they had fun in the course, that their motivation was raised, that they were able to associate what they learned with their daily life, that their problemsolving and design skills improved, and that their awareness about engineering enhanced. It was also found that the students who were successful in the course were less enthusiastic than others at the beginning of the process and that the students had difficulty in matters involving mathematics integration.

\section{Discussion and Conclusion}

The RBS students were found to think that STEM-focused activities contributed to the improvement of their learning process, their 21st-century skills, their perceptions of STEM disciplines and their 
STEM career awareness. According to the RBS students, the activities contribute to the learning process because of their being entertaining, suitable for their making connections to daily life, providing permanent learning, and motivating. They also believe that their 21 st-century skills such as research-inquiry, group work, problem-solving and designing have also developed through these activities. The RBS students evaluated STEM-focused activities to be contributing to their ability to make inferences about the science and engineering relationship, how engineers and scientists work, and the relationships between science and mathematics, and between engineering and mathematics. Furthermore, they were found to think that the activities contribute to their interest in being an engineering and scientist. The findings obtained from the practitioner's field notes, which support this result, show that the course participation and the group work skill of the students increased, that they had fun and became motivated in the course, and that their awareness about engineering enhanced along with the improvement of their skill of associating what they learned with the date life and the skill of designing. Besides, it was found that the students who were successful in the course were less enthusiastic than other students at the beginning of the process and had difficulty in issues involving mathematics integration.

The RBS students stated that their perception and career awareness regarding STEM fields improved. It was also identified through the field notes that the students asked questions about branches of engineering and that they were interested in engineering. Muro and Kottman (1995) report that the secondary school period is important for children to gain awareness about professions. This result of the study indicates the importance of the contribution of the applications to students. As a matter of fact, there are studies indicating that STEM awareness of disadvantaged students is insufficient in the literature (Bozkurt Altan, et al., 2018). Karc1 (2018) showed that STEM-focused activities do not increase students' interest in STEM professions in a low socio-economic region. Gülhan and Şahin (2016) found that STEM activities were effective in improving STEM perceptions and attitudes of 5th grade students. In this respect, it can be suggested that the literature should be enriched by making applied studies for socio-economic disadvantaged groups.

The field notes also confirm that the students evaluated STEM-focused activities to be supporting their 21st-century skills like research-inquiry, group work, problem-solving and design. The field notes also concluded that an improvement was observed in group work, problem solving and design skills. Considering the importance of raising individuals with 21st-century skills (Bybee, 2010), it is important to obtain these outcomes for disadvantaged groups. This result is limited in the views 
of teachers and students. Detailed analysis of all developments can be recommended with various measuring tools.

The field notes also support the fact that the RBS students consider STEM-focused activities to be contributing to their learning process (their being entertaining, suitable for their making connections with daily life, providing permanent learning, and motivating). Likewise, the field notes conclude that the course participation of the students increased, they found the course to be entertaining, their motivation raised and an improvement was observed in terms of their making connections to their daily life. It is believed that the fact that the problems are compatible with the context or the actual life of students is influential on their being motivated for the courses and their ability to utilise their learning for solving their daily life problems. Parker, et al. (2016) point out that opportunities to create STEM learning environments in STEM fields for disadvantaged groups can make contributions suitable to their contexts, even if they do not develop academic knowledge in STEM fields. In this sense, the fact that students project their learning to their real lives is an important result of this study. The importance of problems appropriate to the context and life can be highlighted as another point. The students had difficulty when they needed to use mathematics skills. In order to overcome this problem, it may be suggested that mathematical problems which are based on real life (Karahan \& Bozkurt, 2017) are studied with disadvantaged students. Another result of the study is that students with high academic achievement were shy during the initial activities. This situation is believed to result from their cautious approach to the process of solving problems which they are not used to.

Research that suggests the need for teachers and prospective teachers to carry out STEM training indirectly supports the findings of this research (Bozkurt Altan \& Ercan, 2016; Hacioğlu et al., 2016, 2017; Han et al., 2015; Üçüncüoğlu, 2018; Wang et al., 2011).As a matter of fact, the STEM-focused activities carried out in an RBS which is located in a mountain village were carried out with simple materials, and the positive evaluations made in the students' diaries and the field notes indicate that the application was efficient. It can be stated that the role of the teacher is important for STEMfocused activities towards disadvantaged groups. In support of this result, Scott (2017) draws attention to the fact that the budgetary barrier preventing STEM education from reaching all the segments of society should be overcome and that teachers are essential for ensuring social justice in STEM education. It can be suggested for teacher educators to enrich the studies on the development of action plans for disadvantaged groups by STEM-educated teachers. In parallel, Wong et al. (2017) 
argue that configuration of science and mathematics courses, which have a disciplinary structure, so as to improve STEM literacy is incompatible with industrial and political demands (budget). Stating that this situation impedes the application of STEM education in a way to ensure social justice, the researchers suggest that STEM education activities should be enriched for disadvantaged groups. 


\section{References}

Alsbury, T. L., \& Shaw. N. L. 2005. Policy implications for social justice in school district consolidation. Leadership and Policy in Schools, 4, 105-126.

Bannister, V. R. P., Davis, J., Mutegi, J., Thompson, L., \& Lewis, D. D. (2017). Returning to the root" of the problem: improving the social condition of african americans through mathematics education. Catalyst: A Social Justice Forum, 7(1), 4-14.

Bozkurt Altan, E. (2017a). Fen, teknoloji, mühendislik ve matematik (FeTeMM-STEM) eğitimi [Science, technology, engineering, and mathematics education] Hastürk, H. G. (Ed.), Teoriden pratiğe fen bilimleri ögretimi [Science Education from theory to practice] (pp. 354-388). Turkey, Ankara: Pegem Academy Press.

Bozkurt Altan, E. 2017b. Tasarım temelli fen eğitimi ve probleme dayalı STEM uygulamaları [Design based science education and problem-based STEM education]. In Çepni, S. (Ed.), Kuramdan uygulamaya STEM $+A+E$ Eğitimi $[S T E M+A+E$ Education from theory to practice] (pp. 169-199). Turkey, Ankara: Pegem Academy Press.

Bozkurt Altan, E., \& Ercan, S. (2016). STEM Education program for science teachers: perceptions and competencies. Journal of Turkish Science Education, 13, 103- 117.

Bozkurt Altan, E., Üçüncüoğlu, İ., \& Zileli, E. (2019). Yatılı bölge ortaokulu öğrencilerinin STEM alanlarına yönelik kariyer farkındalığının araştırılması [Investigation of career awareness of STEM fields of the regional boarding secondary schools students]. Kastamonu Education Journal, 27(2), 785-797.

Bybee, R. (2010) Advancing STEM education: a 2020 vision. Technology and Engineering Teacher, 70(1), 30-35.

Çepni, S. (2017). Kuramdan uygulamaya STEM eğitimi [STEM+A+E Education from theory to practice]. Turkey, Ankara: Pegem Academy Press.

Çınar, S., Pırasa, N., \& Paliç Sadoğlu, G. 2016. Views of science and mathematics pre- service teachers regarding STEM. Universal Journal of Educational Research, 4(6), 1479- 1487. 
Çorlu, M. S. (2017). STEM: Bütünleşik Öğretmenlik Çerçevesi [STEM: Framework of integrated Teacher]. In M. S. Corlu, E. Çallı (Eds.), STEM Kuram ve Uygulamaları [Theory and Practice of STEM] (pp. 1-10). Turkey, Ankara: Pusula Press.

Doppelt, Y., Mehalik, M. M., Schunn, C. D., Silk, E., \& Krysinski, D. (2008). Engagement and achievements: a case study of design-based learning in a science context. Journal of Technology Education, 19(2), 22-39.

Dubetz, T., \& Wilson J.A. (2013). Girls in engineering, mathematics and science, GEMS: A science outreach program for middle-school female students. Journal of STEM Education, 14(3), 41-47.

Ellefson, M. R., Brinker, R. A., Vernacchio, V. J., \& Schunn, C. D. (2008). Design-based learning for biology. Biochemistry and Molecular Biology Education, 36(4), 292-298.

Ellis, A., \& Fouts, J. (2001). Interdisciplinary curriculum: The research base: The decision to approach music curriculum from an interdisciplinary perspective should include a consideration of all the possible benefits and drawbacks. Music Educators Journal, $87(22), 22-26,68$.

Enslin, P. (2006). Democracy, social justice and education: feminist strategies in a globalising world. Educational Philosophy and Theory, 38(1), 57-67.

Gale, T. (2000). Rethinking social justice in schools: how will we recognize it when we see it? International Journal of Inclusive Education, 4(3), 253-269.

Gewirtz, S. (2006). Towards a contextualized analysis of social justice in education. Educational Philosophy and Theory, 38(1), 70-81.

Gülhan, F., \& Şahin, F. (2016). Fen-teknoloji-mühendislik-matematik entegrasyonunun (STEM) 5. Sınıf öğrencilerinin bu alanlarla ilgili algı ve tutumlarına etkisi [The effects of science-technology-engineering-math (STEM) integration on 5th grade students' perceptions and attitudes towards these areas.]. International Journal of Human Sciences, $13(1), 602-620$.

Hacıoğlu, Y., Yamak, H., \& Kavak, N. (2016). Mühendislik tasarım temelli fen eğitimi ile ilgili öğretmen görüşleri [Teachers' Opinions Regarding Engineering Design Based ScienceEducation]. Bartin University Journal of Faculty of Education, 5(3), 807-830. 
Hacioğlu, Y., Yamak, H., \& Kavak, N. (2017). The opinions of prospective science teachers regarding STEM education: The engineering design based science education [The opinions of prospective science teachers regarding STEM education: the engineering design-based science education]. Gazi University Journal of Faculty of Education, 37(2), 649-684.

Han, S., Yalvac, B., Capraro, M. M., \& Capraro, M.R. (2015). In-service teachers' implementation of and understanding from project-based learning (PBL) in science, technology, engineering, and mathematics (STEM) project-based learning. Eurasia Journal of Mathematics, Science ve Technology Education, 11(1), 63-76.

Karahan, E. (2015). Fantastik bir STEM masalı: robotların yükselişi [A fantastic STEM tale: the rise of robots]. Retrieved from https://enginkarahan.com/2015/02/08/fantastik-birstem-masali-robotlarin-yukselisi/

Karahan, E., \& Bozkurt, G. (2017). STEM Eğitiminde matematiksel odaklı gerçek dünya problemleri ve matematiksel modelleme [Mathematical real-world problems and mathematical modeling in STEM Education]. Çepni, S (Ed.), Kuramdan uygulamaya STEM $+A+E$ Eğitimi [STEM $+A+E$ Education from theory to practice] (pp. 353-372). Turkey, Ankara: Pegem Academy Press.

Karcı, M. (2018). STEM etkinliklerine dayalı senaryo tabanlı öğrenme yaklaşımının (stöy) öğrencilerin akademik başarıları, meslek seçimleri ve motivasyonları üzerine etkisinin incelenmesi [Examining the effect of using scenario based teaching method based on STEM activities on students' achievement, career choice and their motivation]. (Unpublished master thesis). Available from Turkish Thesis Center (No. 509021).

Kınık Topalsan, A. (2018). Sınıf öğretmenliği öğretmen adaylarının geliştirdikleri mühendislik tasarım temelli fen öğretim etkinliklerinin değerlendirilmesi [Evaluatıon of The Elementary School Teacher Candidates’ Engıneerıng Design Based Science Instruction Activities]. YYU Journal of Education Faculty, 15(1), 186-219.

Köroğlu, E., \& Bozkurt Altan, E. (2017, April). Planning of the 8th class "Living and Energy" unit for STEM education. Paper presented at $26^{\text {th }}$ International Conference on Educational Science, Antalya, Turkey. 
Lowrie, T., Downes, N., \& Leonard, S. (2018). STEM Education for all young Australians. A Bright spots stem learning hub foundation paper for SVA, in partnership with Samsung. University of Canberra STEM Education Research Centre.

Madden, P. E., Wong, C., Cruz, A. C. V., Olle, C. D., \& Barnett, M. (2017). Social justice driven STEM learning (STEMJ): A curricular framework for teaching STEM in a social justice driven, urban, college access program. Catalyst: A Social Justice Forum, 7(1), 2437.

Ministry of Education (2003). Yatılı İlköğretim Bölge Okulları ve Pansiyonlu İlköğretim Okulları Yönetici Kılavuz Kitabı [Regional directory of boarding primary schools and primary schools with pensions executive guide book], Turkey, İstanbul: Ministry of Education Press.

Ministry of Education (2016). Fen bilimleri dersi öğretim programı [Science Curriculum] Turkey, Ankara: Ministry of Education Press.

Muro, J., \& Kottman, T. (1995). Guidance and counseling in the elementary and middle schools. Dubuque, IA: Brown \&; Benchmark.

National Academy of Engineering [NAE] \& National Research Council [NRC] (2009). Engineering in $\mathrm{K}-12$ education understanding the status and improving the prospects. Edt. Katehi, L., Pearson, G. \& Feder, M. Washington, DC: National Academies Press.

National Research Council [NRC]. (2012). A Framework for k-12 science education: practices, crosscutting concepts, and core ideas. Washington DC: The National Academic Press.

Parker, C.E., Pillai, S., \& Roschelle, J. (2016). Next generation STEM learning for all: A report from the NSF supported forum. Waltham, MA: Education Development Center.

Peterman, K., Daugherty, J. L., Custer, R. L., \& Ross, J. M. (2017). Analysing the integration of engineering in science lessons with the engineering-infused lesson rubric. International Journal of Science Education, 39(14), 1913-1931.

Rogers, C., \& Portsmore, M. (2004). Bringing engineering to elementary school. Journal of STEM Education: Innovations \& Research, 5(3/4), 17-28.

Sanders, M. (2009). STEM, STEM education, STEMmania. The Technology Teacher. 68(4): 20-26. 
Sarı, U. (2018). Disiplinlerarası fen öğretimi: FeTeMM eğitimi [Interdisciplinary science teaching: STEM education]. Karamustafaoğlu, O.; Tezel, Ö.; Sarı, U. (Eds.). Güncel yaklaşım ve yöntemlerle etkinlik destekli fen ögretimi [Activity-supported science teaching with current approaches and methods]. (pp. 286-324). Turkey, Ankara: Pegem Academy Press.

Schnittka, C., \& Bell, R. (2011). Engineering design and conceptual change in science: addressing thermal energy and heat transfer in eighth grade. International Journal of Science Education, 33(13), 1861-1887.

Scott, C. (2017). STEM education and social justice. Catalyst: A Social Justice Forum, 7(1), 12.

Shaughnessy, M. (2013). Mathematics in a STEM context. Mathematics Teaching in the Middle School, 18(6), 321-323.

Smith, J., \& Karr-Kidwell, PJ. (2000). The interdisciplinary curriculum: a literary review and a manual for administrators and teachers. Retrieved from ERIC database. (ED443172).

Sondel, B., Koch, J., Carrier, S., \& Walkowiak, T. (2017). Toward a theory of teacher education for justice-oriented STEM. Catalyst, 7(1), 38-52.

Sturman, A. (1997). Social justice in education. Camberwell Victoria: ACER Press.

Turkish Language Institution (2018). Current Turkish Dictionary, Retrieved April 25, 2018, from http://www.tdk.gov.tr/index.php?option=com_bts\&view=bts\&kategori1=veritbn\& kelimesec $=288671$.

Üçüncüoğlu, İ. (2018). Fen bilgisi öğretmen adaylarına yönelik STEM odaklı laboratuvar uygulamalarının tasarlanması ve etkililiğinin araştırılması [STEM-focused design and efficiency investigation of laboratory applications for pre-service science teachers]. (Unpublished master thesis). Available from Turkish Thesis Center (No. 513968).

Wang, H. H., Moore, T. J., Roehrig, G. H., \& Park, M. S. (2011). STEM integration: teacher perceptions and practice. Journal of Pre-College Engineering Education Research, 1(2), $1-13$.

Wendell, K. B. (2008). The theoretical and empirical basis for design-based science instruction for children. Qualifying Paper, Tufts University. 
Wong, V., Dillon, J., \& King, H. (2017). STEM and social justıce: mutually incompatible?. European Science Education researchh Association (ESERA) Conference, Dublin City, Dublin, Ireland.

Yin R. K. (2009). Case study research: Design and methods (4th ed.). SAGE Pub. Thousand Oaks, California. 
Appendix 1. Analysis Framework of Students' Diaries

\begin{tabular}{ll}
\hline Theme & Codes \\
\hline Contributions to the Process of & - Fun \\
Learning & - Connection to daily life \\
& - Permanent learning \\
& - Motivates to learn \\
\hline Contributions to the & - Research and inquiry \\
Development of 21st-Century & - Group work \\
Skills & - Problem-solving skill \\
& - Designing skills \\
\hline Contributions to the Perception & - Science and engineering relationship \\
about STEM Disciplines & - Engineers working process \\
& - Scientists working process \\
& - Science and mathematics \\
& - relationship \\
& Engineering and mathematics \\
& relationship \\
\hline Contributions to Developing & - Interest in engineering \\
\hline
\end{tabular}

Appendix 2. Analysis Framework of Teachers' Field Notes

\begin{tabular}{ll}
\hline Theme & Codes \\
\hline $\begin{array}{l}\text { Contributions to the } \\
\text { Process of Learning }\end{array}$ & $\bullet$ Fun \\
& $\bullet$ Connection to daily life \\
& Motivates to learn \\
\hline $\begin{array}{l}\text { Contributions to the } \\
\text { Development of 21st- }\end{array}$ & $\bullet$ Problem-solving skill \\
Century Skills & $\bullet$ Designing skills \\
\hline $\begin{array}{l}\text { Contributions to } \\
\text { Developing STEM } \\
\text { Career Awareness }\end{array}$ & $\bullet$ Interest in engineering \\
\hline $\begin{array}{l}\text { Difficulties } \\
\text { experienced in the } \\
\text { process }\end{array}$ & $\bullet$ \\
\end{tabular}

